\title{
Kaupunkitutkimus muutoksessa
}

\author{
Mervi Ilmonen
}

Museokierrokselta tullessani päätin käydä toistamiseen Friedrichstrassen Kulturkaufhaus Dussmannissa. Olin aamupäivällä viettänyt aikaa sen musiikkiosastolla, innostuneena ja harmistuneena. Tarjonta huimasi: klassisen ja elokuvamusiikin aarteita, Beethovenin 250-vuotissyntymäpäivä oli näkyvästi esillä. Helsingissä ei enää ole ainuttakaan isoa musiikkikauppaa, jossa voisi skannata tarjontaa monipuolisesti. Aivan, tiedän mitä aiotte sanoa, mutta netistä ei helposti löydä sellaista, minkä ei tiedä olevan olemassa enkä pidä ainoastaan virtuaalisessa muodossa olevasta musiikista.

Berliinin ja Helsingin merkittävä ero on kriittisen massan määrä. Monet etenkin ekologisen kaupunkitutkimuksen käsitteistä on lainattu luonnontieteistä, niin myös kriittinen massa, jolla tarkoitetaan fysiikassa fissiokelpoista materiaalia, joka kykenee itseään ylläpitävään ketjureaktioon. Kaupunkitutkimuksessa sillä tarkoitetaan karkeasti sitä, että riittävä määrä ihmisiä pienellä alueella tuottaa mahdollisuuksia ja diversiteettiä. Helsinkikin on kaupunkina jo iso ja monipuolistuva, mutta ei vielä tarpeeksi kumpaakaan. Riittävän monipuolisuutta tuottavan massan puute näkyy monessa asiassa vähäisenä tarjontana, varovaisuutena ja riskittömänä main streamiin tukeutumisena.

Kävin vielä tutkimassa Dussmannin englanninkielisten kirjojen hyllyn. Yleensä muunkielisten kirjojen nimikkeiden kirjo on missä tahansa maassa melko vaatimaton eikä Dussmanninkaan hylly Feminist Theory and Sociology -- tässä järjestyksessä -- näyttänyt etäältä vakuuttavalta. Hyllyn äärellä pöyristyin. Suoraan edessäni oli Richard Sennettin ${ }^{1}$ Building and Dwelling: Ethics for the City². Ällistykseni johtui siitä, että en tuntenut tätä merkittävän

1 Sennett, R. (2019). Building and Dwelling. Ethics for the City. Penguin books. Random House, UK.

2 Robert Beauregardin arvio kirjasta on täällä: Beauregard, R. (2019). Richard Sennett 2018: Building and Dwelling: Ethics for the City. London: Penguin Books (Book review). International Journal of Urban and Regional Research 43: 3. https://doi. org/10.1111/1468-2427.12801 
tieteellisen auktoriteettini viime vuonna ilmestynyttä kirjaa. Pidän itseäni melko valppaana alan keskustelunavausten ja tärkeiden julkaisujen seuraajana. Mutta olinko lukenut IJURR:n huolimattomasti, laiskistunut lukijana vai ollut huomaamatta oleellista keskellä minulle tulevien sähköpostitiedotteiden muodikasta artikkeliroskaa? Miten tahansa, ostin kirjan ja vierestä sen kaverin Together ${ }^{3}$, osaksi pitkähköä Sennett-osastoa kirjahyllyssäni.

On useita syitä, miksi kiinnostuin kaupunkitutkimuksesta. Lapsuudessani ja nuoruudessani Suomessa vallitsi vahva kaupunkikielteisyys ja suoranainen vihamielisyys, jota neljännen polven helsinkiläisenä aina ihmettelin. Helsinkiläisyys oli taakka heti kaupungin rajojen ulkopuolella. Lapsuuteni Fiskarsissa olin sen ajan helsinkiläisiin liitetyn stereotypian mukaan enimmäkseen koppava hesalainen, vaikka en kokenut leimaa aiheelliseksi. Kaupunkilaisuuden ja kaupungin pohtiminen kiinnosti yliopistollakin ryhtyessäni opiskelemaan.

Opintojeni alkuaikoina Sennett oli yksi kaupunkitutkimukseen kohdistuvan kiinnostukseni innoittajista. Vuonna 1969 julkaistu Classic essays on the culture of cities ${ }^{4}$ oli havahduttava kirja, johon hän oli koonnut merkittävimmät kaupunkikulttuuria koskevat esseet: Weberin, Simmelin, Spenglerin, Parkin sekä Redfieldin ja Singerin tekstit. Yhdessä Sennettin johdannon kanssa kirja on tiivis ja syvällinen johdanto kaupunkien kulttuuriseen olemukseen. Sen avulla kuka tahansa aiheesta kiinnostunut saa edelleen haltuunsa alan tärkeimmät käsitteet ja hyvän perussivistyksen. Kopioin valtsikan kirjaston ja luultavasti koko Suomen ainoan kappaleen kirjaa, ja moniste oli tärkeä aarteeni vuosikausia.

Sosiaalipolitiikassa oli tuolloin mahdollista valita erikoisaloiksi asuntopolitiikka ja aluepolitiikka - kaupunkitutkimuksesta ei silloin puhuttu missään. Olin valinnut ne, mutta Heikki Wariksen ${ }^{5}$ kestävää väitöskirjaa lukuun ottamatta tenttikirjat eivät minua puhutelleet. Sennettiä ei opetuksessa tunnettu, ei myöskään esimerkiksi Mumfordia ${ }^{6}$ eikä edes Sven-Erik Åströmia ${ }^{7}$. Puutteelliseksi kokemani opetus sai minut etsimään tietoa opetuksen ulkopuolelta ja muualta kuin omalta laitokselta. Opiskelin jonkin aikaa suunnittelumaantiedettä, joka avasi uudenlaisia näkökulmia fyysiseen ympäristöön. Maantieteen opiskelun yhteisöllisyys virkisti, mutta maantieteilijöiden vähäinen lukeneisuus kummastutti. Kun sain assistentin viransijaisuuden silloisesta Teknillisen korkeakoulun Yhdyskuntasuunnittelun jatkokoulutuskeskuksesta $\left(\mathrm{Y} \mathrm{JK}^{8}\right)^{8}$, tuntui että pääsin kotiin. YJK:n

\footnotetext{
3 Sennett, R. (2013). Together. The Rituals, Pleasures and Politics of Cooperation. Penguin books. Random House. UK. 4 Appleton-Century-Crofts, New York.

5 Waris, H. (1932/1973). Työläisyhteiskunnan syntyminen Helsingin Pitkänsillan pohjoispuolelle. Weilin + Göös, Helsinki.

6 Mumford, L. (1949). Kaupunkikulttuuri. WSOY, Porvoo.

7 Åström, S-E. (1957). Samhällsplanering och regionsbildning i kejsartidens Helsingfors: Studier i stadens inre differentiering 1810-1910. Helsingfors stads publikationer 6. Helsingfors.

8 Sittemmin YTK (Yhdyskuntasuunnittelun tutkimus-ja koulutuskeskus), nyt osa Aalto-yliopiston Rakennetun ympäristön laitosta.
} 
monitieteisyys, jossa yhdistyivät kaupunkitutkimus, alue- ja kaupunkisuunnitURBAN STUDIES telu sekä läheinen yhteys käytännön suunnitteluun ja kuntatasoon tekivät siitä hyvin poikkeuksellisen paikan. Laitoksessa, kuten TKK:ssa yleisemminkin, oli hyvin matala hierarkia, aivan toisin kuin nykyisessä Aalto-yliopistossa. Se teki mahdolliseksi laitoksen hyvän hengen ja aloitteellisuuden. Ne useat kaupunkitutkimuksen ja -suunnittelun monitieteisyyttä edistäneet hankkeet, joita olin perustamassa tai järjestämässä, kuten esimerkiksi Stadipiiri (1994-200o), alan ensimmäinen monitieteinen Kaupunkitutkimuksen ja -suunnittelun tutkijakoulu (1999-2002) tai Kaupunkitutkimuksen päivät (2002-), sen enempää kuin merkittävien vierailuprofessorien kutsuminen, eivät olisi olleet mahdollisia ilman YJK:n (myöhemmin YTK:n) tukea ja sen antamaa toimintavapautta.

Ensimmäisiä töitäni oli opponoida Maanmittaustekniikan laitoksen diplomi-insinööri Anne Hailan sivuainetutkielmaa YJK:n tutkimusseminaarissa. Annen tutkielma koski marxilaisen radikaalimaantieteen keskeisen tutkijan David Harveyn tuotantoa ja ajattelua. Harvey oli jo julkaissut useamman kaupunkimaantieteen paradigmaa uudistavan teoksen, kuten Social Justice and the City ${ }^{9}$ ja The Limits to Capital ${ }^{10}$, mutta oli etenkin Suomessa vielä huonosti tunnettu. Minäkin tiesin Harveyn vain nimeltä, joten tutkielman opponointi innosti lukemaan teoksia. Radikaalimaantieteilijöiden kiinnostus kaupunkiin ja kaupungin ottaminen analyysin kohteeksi oli uutta ja innostavaa. Opponointitilaisuudessa puidut nykyään tavalliset ja jo osin ohitetutkin käsitteet kuten oikeus kaupunkiin tai näkemys kaupungista luokkasuhteiden valtakamppailuna eivät olleet silloin valtavirtaa. Säilytin tutkielmaa pitkään, sillä se oli Annen tapaan tarkka analyysi ja erinomainen johdanto Harveyn ajatteluun.

Tuon ensitapaamisen jälkeen olin paljon tekemisissä Annen kanssa, erityisesti sen jälkeen, kun Annesta tuli Yhdyskuntasuunnittelu11-lehden päätoimittaja ja hän pyysi minut lehden toimitussihteeriksi. Tieteellinen kirjoittaminen ei 1990-luvulla ollut vilkasta, joten koska lehteen oli usein vaikea saada aineistoa, suomensimme toisinaan yhdessä englantilaisista tai amerikkalaisista tiedelehdistä valittuja artikkeleita. Toimituksen osallistuminen kokouksiin oli yhtä satunnaista kuin nykyäänkin ja vastuu oli ja on edelleen vahvasti päätoimittajalla ja toimitussihteerillä. Annen päätoimittajakaudella lehti tieteellistyi ja kansainvälistyi. Anne kirjoitti tuolloin itse lehteen paljon, teki kirja-arvioita ja toi tietoisuuteen tiedeyhteisön keskusteluaiheita.

Kun ajattelen mistä ja missä olen parhaiten oppinut kaupunkitutkimuksesta, niin ensimmäinen kouluni oli Helsingin yliopisto, sen sosiaalipolitiikan

9 Harvey, D. (1973). Social Justice and the City. University of Georgia Press.

10 Harvey, D. (1982). The Limits to Capital. Basil Blackwell. Oxford.

11 Lehti aloitti Yhdyskuntasuunnittelu-nimisenä 1968. Nimi muuttui välillä Yhteiskuntasuunnitteluksi, joka se oli Anne Hailan päätoimittajakaudella. Myöhemmin nimi muutettiin takaisin Yhdyskuntasuunnitteluksi. 
ja maantieteen laitokset, toinen Teknillisen korkeakoulun YTK, ja kolmas merkittävä oppimisen paikka Yhdyskuntasuunnittelu-lehti Annen kanssa. Yhteistyössämme opin paljon kaupunkitutkimuksen teorioista, kansainvälisestä tutkimusyhteisöstä ja kirjoittamisesta. Anne oli uransa alusta asti vahvasti kansainvälisyyteen suuntautunut. Hänen väitöskirjansa12 oli englanniksi kirjoitettu artikkeliväitöskirja, mikä ei tuolloin ollut tavallista.

Anne vaikutti myös omaan kansainvälistymiseeni, madaltaen kynnystä osallistua tilaisuuksiin, joissa oli vielä 1990-luvulla hyvin vähän suomalaisia osallistujia. Ensimmäisiä isoja kansainvälisiä kokouksiani oli International Sociological Associationin (ISA) 12. maailmankonferenssi Madridissa heinäkuussa 1990. Anne toimi siellä yhden session puheenjohtajana Susan Fainsteinin järjestämässä työryhmässä. J-P Roos ja Keijo Rahkonen olivat konferenssissa, mutta vain minä ja kaupunkisuunnitteluviraston tutkimuspäällikkö Raimo Kostiainen seurasimme johdonmukaisesti kaupunkiryhmää "Research Committee 21: Urban and Regional Development".

RC 21:n tehtävänä on edistää sosiologisen kaupunki- ja aluetieteen teorian kehitystä ja alan tutkijoiden yhteyttä. Siihen ovatkin kuuluneet maailman merkittävimmät kaupunkitutkijat sen perustamisesta 1970 alkaen ${ }^{13}$. Sitä ennen kaupunkitutkimus ei ollut edustettuna järjestössä kuin epäsuorasti, sillä olihan 1949 perustetun ISA:n ensimmäinen puheenjohtaja itse Louis Wirth, usein maailman vaikutusvaltaisimmaksi sanotun kaupunkiesseen kirjoittaja ${ }^{14}$. RC 21:stä muodostui myös Annen tärkein tutkijayhteisö, jossa hän toimi aktiivisesti koko uransa ajan ${ }^{15}$.

Anne oli aktiivinen osanottaja myös Amerikan maantieteilijöiden AAG:ssa (American Association of Geographers), jonka massiivisista vuosikonferensseista on erityisesti 2010-luvulla tullut monien suomalaisten kaupunkitutkijoiden osallistumiskohde. Viime vuosina näinkin Annen lähes useammin AAG:n kokouksissa kuin kotimaassa. Kaupunkisuunnittelun alan kokouksiin osallistumisesta Anne luopui vähitellen. Luulen, että viimeisen kerran olimme samanaikaisesti Oxfordissa järjestetyssä amerikkalaisten ja eurooppalaisten, AESOP:n ${ }^{16}$ ja ACSP: $\mathrm{n}^{17}$ yhteiskonferenssissa 1991, jossa skannasimme sessioita ja vietimme aikaa Blackwellin ihanassa kirjakaupassa. Minulle erityisesti AESOPista tuli tärkeä yhteistyöfoorumi ja viiteryhmä, jonka toimintaan ja tapahtumiin osallistuin.

12 Haila, A. (1990). Land as a financial asset: studies in theoretical and real trends. Teknillinen korkeakoulu. Maanmittaustekniikan laitos. Kiinteistöoppi. Otaniemi.

13 Past RC 21 boards: 〈http://www.rc21.org/en/past-rc21-boards/>

14 Wirth, L. (1938). Urbanism as a Way of Life. American Journal of Sociology 44:1 (Jul. 1938), 1-24. https://doi. org/10:1086/217.913

15 Johtokunnan jäsen 1991-1994, varapresidentti kahteen kertaan 1995-1998 ja 2002-2006, sihteeri 1998-2002.

16 Association of European Schools of Planning

17 Association of Collegiate Schools of Planning 
Järjestin myös AESOPin 2010 lähes tuhat ihmistä keränneen vuosikongressin Helsinkiin ja Otaniemeen, yhdessä kaupunkiprofessori Peter Achen kanssa.

Kaupunkitutkimus on opiskeluni alkuajoista muuttunut perusteellisesti sekä Suomessa että muualla. Suomi vaikutti aloittaessani vielä agraariselta periferialta, jossa kaupunkikysymykset eivät teoreettisesti kiinnostaneet ketään, mutta toisin on nyt. Kaupunkitutkimusta tehdään monilla eri tieteenaloilla, Suomessakin on vahvoja kaupunkitutkijoita ja alkaa olla jopa tutkimusperinnettä.

Myös kaupunkitutkimuksen kohteet ja tutkimuskysymykset ovat monipuolistuneet ja globaalistuneet. Amerikkalainen kaupunki oli kauan myös eurooppalaisen kaupunkitutkimuksen fokuksessa, sillä yhteiskuntatieteellinen kaupunkitutkimus on erityisesti amerikkalainen keksintö, joka syntyi teollisen kaupungin kaaoksesta, epäjärjestyksestä ja epäoikeudenmukaisuudesta. Ensimmäiset 1920luvun Chicagon ekologisen koulun kaupunkisosiologit jättivät siksi raskaan ja pitkän tutkimusperinnön. He eivät erityisesti pitäneet kaupungista ja tutkimuksen kohteiksi valikoituivat kaupunkien ongelmat. Kaupunkia myönteisinä ominaisuuksina ja kokemuksina on ryhdytty johdonmukaisemmin tarkastelemaan vasta 1980-luvulta alkaen, tutkimuksellisen kulttuurisen käänteen ja kaupunkien kasvun seurauksina. 1900-luvun lopun kaupunkitutkimuksen kohteina olivat erityisesti globaalin pohjoisen teolliset kaupungit ja kaupunkiteoriat selittivät niiden kehitystä18. Nykyiset kaupunkitutkijat eivät enää puhu vain Chicagosta, Los Angelesista ja New Yorkista, eivätkä Pariisista tai Lontoosta, vaan tutkijoiden kartalle ovat tulleet myös pienet ja perifeeriset kaupungit maapallon kaikista kolkista. Vaikka angloamerikkalainen kaupunkikeskustelu ja eurosentrisyys on vieläkin vahvasti esillä kaupunkitutkimuksessa, eivät Aasian ja Afrikan kaupungit ole enää ainoastaan eksoottisia ulkopuolisia, vaan omanlaistaan kaupunkidynamiikkaa edustavia tutkimuskohteita.

Pierre Bourdieaun mukaan sosiologia on taistelulaji. Väitettä voi soveltaa muihinkin tieteenaloihin, ehkä erityisesti juuri kaupunkitutkimukseen, jonka monitieteisyys, läheinen suhde toteutukseen ja politiikkaan haastavat tutkimusstrategian ja tutkijan integriteetin. Anne Hailan edustaman kriittisen kaupunkitutkimuksen lähtökohtana on pyrkimys oikeudenmukaisempien ja parempien rakenteiden tuottamiseen sekä ilmiöiden syvärakenteiden ja merkitysten tunnistamiseen. Prosessien ja rakenteiden kyseenalaistaminen on paradigmojen ja tarkastelukohteiden muutoksista riippumaton kaupunkitutkimuksen kestävä tutkimusstrategia.

18 Roger Keil pohtii kaupunkitutkimuksen muutoksia IJURR:n 40-vuotisnumerossa. Keil, R. (2017). "There were, in fact, perhaps only four types of cities in that imaginary: the (western) European city, the socialist city (mostly in the East), developing cities (mostly in the South) and the American city (mostly in America; I don't think Asian cities were much on anyone's radar screen at the time). <https://www.ijurr.org/spotlight-on/urban-studies-at-ijurrs-4oth-anniversary/ roger-keil/s 